Katarina Ivanić, M.Sc.

E-mail: kathrin.nic@hotmail.com

Svjetlana Hess, Ph.D.

E-mail: shess@pfri.hr

University of Rijeka, Faculty of Maritime Studies, Studentska 2, 51000 Rijeka, Croatia

\title{
Review of Technological Processes at the Container Terminal
}

\begin{abstract}
The aim of this paper work is to explore technological processes which occur on container terminal. Each of them represents a sort of a challenge for a manager of every port, who is responsible for a work organization. The way of running technological processes needs to be organized by minimizing the time ships spend on a dock, including balanced and economical use of port capacity as well as maximum flow of containers. Tracking efficiency of port capacities is shown on an example of container terminal of Rijeka port. By applying quantitative methods, queuing theory, it is been explored whether the capacity of container terminals satisfy existing trade as well as whether the same are sufficient for future increase of trade in terms of expansion of existing or better organization of technological processes.
\end{abstract}

Keywords: technological processes, container terminals, port capacities, efficiency

\section{Introduction}

The collapse of many market barriers as well as their globalization have brought about competition among terminals which ultimately leads to terminals forced to improve the services they offer to clients. An efficient terminal is the one with fast loading/unloading of containers. By managing terminals using effective quantitative methods, it is possible to achieve effective and economical use of port capacity which satisfies the needs of barges, which require fast and effective service for their ships. The problem of every port is to find a solution which will enable the most effective transhipment of containers. The solution for any port would be to provide loading/ unloading operations in the best possible way, that is, to optimize them within their available recourses, while satisfying their clients. The lack or insufficient capacity of 
wagons, towing vehicles or warehouses leads to consequences involving decisions on the most expensive solutions of investing in port. Therefore, the primary task is to avoid the most expensive decision which would increase the cost of loading and unloading.

During unloading, both towing vehicles and shore cranes should be available, to assure continuous process of unloading. From a logistical point of view, increase in productivity of terminals is not achieved by increasing the number of towing vehicles or their speed. The reason is that the possibility of stagnation grows at a faster rate than proportional with the number of towing vehicles or their speed. Every terminal aims to find their optimal loading/unloading solution, considering the optimal speed of cargo transport (ship and shore cranes, forklifts, towing vehicles, tractor trailers) as well as the moving direction of cargo inside the port, which falls among the most important tasks of the port. In this article, a research study is carried out of technological processes taking place on terminal during the process of unloading and stacking of containers. There is also a section dealing with former researches on individual processes, as well as on all the possibilities for improvements in the organization of those technological processes aimed at ensuring the achievement of the ultimate goal, minimizing ships' time spent on terminal. The last section presents one of the ways to analyse the efficiency of the port of Rijeka container terminal using the queuing theory.

\section{Defining the problem}

When vessels sail into port, it is important to make their waiting time as short as possible, since waiting costs for ship owners are very high. The terminal receives detailed information about an incoming vessel before its arrival in order for containers that are to be loaded on board to be prepared upfront, and it is also known which containers are to be discharged into the yard. The data about the vessel enable the terminal staff to develop a detailed sequence of tasks for each quay crane and to determine the order of containers that are to be loaded and unloaded, as well as the locations the containers will be taken from and transported to. A fleet of towing vehicles transports the containers from the vessel to the yard and vice-versa. And finally, a detailed schedule for each yard crane must be determined. 


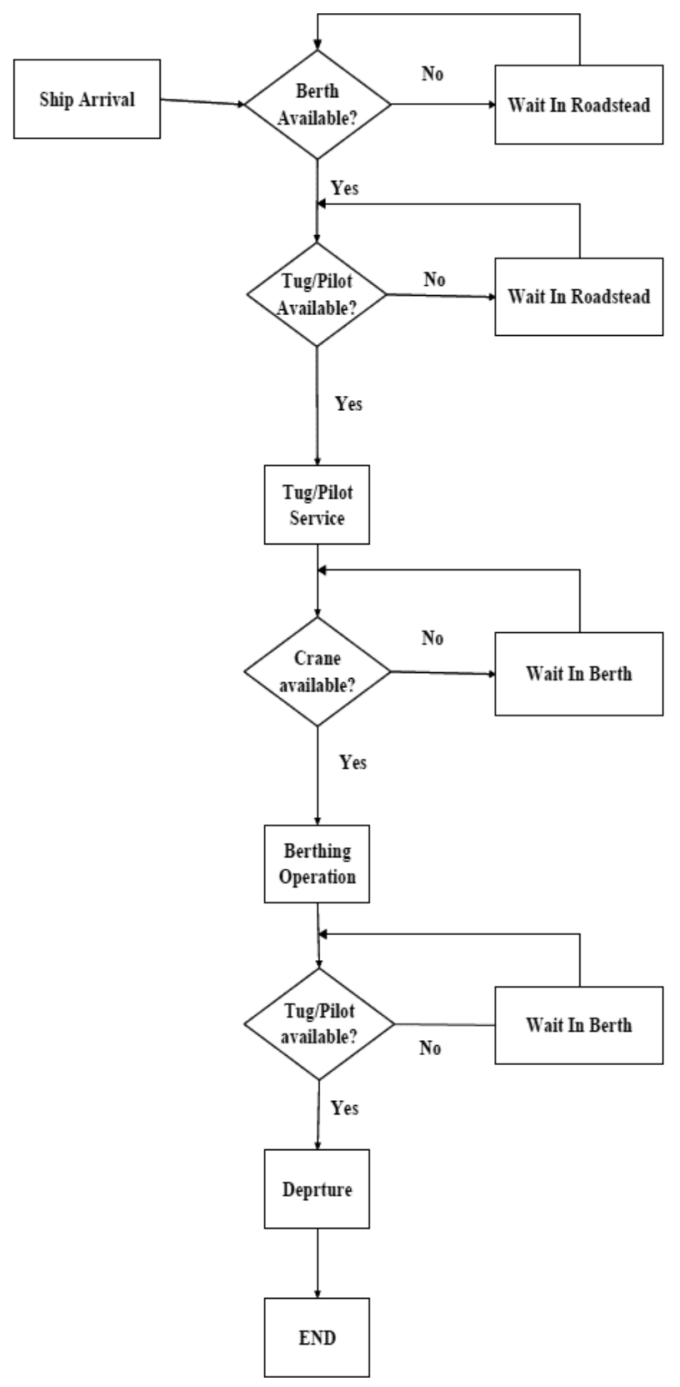

Scheme 1 - The algorithm of vessel's landing, loading/unloading, and departure processes

Source: Hashemia A. et al. [1, pp.2]

Depending on the available berth, the vessel receives permission to moor and proceeds to the designated mooring place. If there is an available berth, but no available pilot or tugboat, the vessel needs to wait in the mooring place until the first pilot is free to pilot it. After the piloting, the vessel comes to the designated wharf and, provided that 
the quay cranes are available, the process of freight (containers) unloading can start. When choosing the container handling method, one must bear in mind that the container terminal should be located in a way to enable quick access to roads and railways.

Problems that may arise in organizing a container terminal are not easily solvable, and attention should be paid to numerous details already in the stage of planning the construction of the terminal. Since container vessels and port resources are quite expensive, the main objective of quay activities is to handle vessels within the shortest time possible, whereby the utilization rate of terminal resources (such as the quay, quay cranes, yard cranes, towing vehicles etc.) should be as high as possible.

\section{A summary of technological processes at the terminal with reference to previous research}

The transportation-technological process encompasses the entirety of technical and technological procedures and organisational measures that need to be implemented in order to ensure efficient and uninterrupted flow of traffic while carrying out a certain transportation task. Transportation-technological processes may come in two forms: simple and complex. A simple transportation-technological process takes place between the consignor and consignee where there is no interruption of transport and no quantitative or qualitative change of the load caused by changes in the transportation system. If there is a change of the mean of transport with or without the storage of the load, then the transport-technological process is complex [2, pp.1].

The productivity of a container terminal can be measured by the productivity of two types of technological operations. The first type refers to loading of containers on the vessel and discharging them from it, while the second type is related to transporting the containers to the yard using towing vehicles. The key goal is to optimize the time between container loading/discharging and the utilization of port capacities.

\subsection{The berth allocation process}

In most container terminals the number of berths does not change, therefore the main problem on the terminal is how to allocate those berths to the incoming vessels in order to achieve the optimal performance of the terminal. When it comes to the berth allocation problem, the following things should be taken into account: vessel's features (its schedule, size, the number of containers to be loaded and discharged), features of the resources (the number of berths and the number of quay cranes at each berth) and physical conditions (depth of the water, length of the berth, etc.). In an ideal situation, container terminals should organize berths in a way which will enable all the berths to be occupied all the time and vessels not to have to wait. However, this is impossible to be achieved in practice due to uncertainties concerning vessels' arrivals, fluctuations in container handling rates and unforeseen needs encountered in discharging and loading 
operations. Therefore, finding an optimal berth allocation plan is very important for the optimization of quay operations. The objectives of berth allocation are the following:

$>$ minimal vessels' waiting time and minimal port expenses,

$>$ minimal distance between the berth and the yard where containers are to be stacked, so that the time needed for the transportation of containers between the berth and the yard is minimal, and

$>$ maximal utilization of berths and quay cranes.

When it comes to the berth allocation problem, we usually make a distinction between two main types: one in discrete locations and the other in continuous locations. The first type is called the discrete berth allocation problem (BAPD) and the second is called the continuous berth allocation problem (BAPC).

Numerous studies on the discrete berth allocation problem have been carried out so far. Lai and Shih (1992) suggested a heuristic algorithm for solving the berth allocation problem and they wanted to achieve a more efficient utilization of the international terminal in Hong Kong. Such algorithms tend to be iterative [9, pp.15]. The search for a solution begins with a trivial solution which is often far from optimal. With every iteration occurred, they modify the current solution in order to come closer to the optimal one [6].

Brown et al. $(1994,1997)$ studied ship handling in sea ports. They established an optimal series of operations from which the ships benefit the most. Imai et al. (1997) developed a heuristic algorithm for the static berth allocation problem in order to achieve two goals: minimal handling time and minimal dissatisfaction of ships with the sequence of services. Nishimura et al. (2001) extended the dynamic berth allocation problem in order to take into account some physical restrictions in berthing ships, such as the depth of the water and the length of the berth. A non-linear integer program was developed for that problem. Since the non-linear integer program was difficult to solve, they used genetic algorithms in order to obtain approximate solutions to the problem [9, pp.15-17].

Some researchers have also examined the allocation of continuous berths, which are very flexible; by using them, better productivity and utilization can be accomplished than by using discrete berths. Lim (1998) studied the problem of assigning a series of vessels to different berths of a port, taking into consideration various limitations, such as vessels' preferred locations in the berth and the distance between the berths' ends. Park and Kim (2002) studied the continuous berth allocation problem with the objective of minimizing the expenses caused by the delay in vessels' departures due to inconvenient sequence of services performed and other complications with the handling of containers. Imai et al. (2005) dealt with the continuous berth allocation problem with the goal of minimizing the total handling time. In their research, the handling time depended on the ship's location in the quay. They developed a two-stage heuristic algorithm to solve the problem. In the first stage, the algorithm offered a solution based on the number of partitioned berths, and in the second stage another procedure was applied in order to 
move the ships which may be overlapping or may be too far away. According to those experiments, the suggested principle might be used in order to find a starting solution using the discrete berth allocation, which then might be improved using the continuous berth allocation [9, pp.17-18].

\subsection{The process of loading and discharging a vessel}

Once a vessel is docked at the berth, quay cranes can start discharging and loading containers. The efficiency of handling vessels depends on scheduling and allocating the quay cranes to the vessels. When scheduling quay cranes, vessels' features (the place of docking, schedule, size, the number of containers to be discharged and loaded and the total number of vessels to be handled) and the features of resources (average number of towing vehicles per quay crane and the total number of quay cranes) are taken into account. When organizing quay cranes, a certain number of cranes is allocated to one ship and to its bays on hold and deck and decision is made in respect of the bays' operation schedule. It doesn't reflect only upon one vessel, but upon several vessels (the neighbouring vessels as well as practically all the vessels that are at the terminal at a certain moment).

When it comes to loading a vessel, there are two basic planning steps. In the first step, the types of containers that are to be stacked in various parts of the vessel are planned. In the second step, the terminal determines the location for each container to be put on board the container vessel, bearing in mind the vessel's stability and loading limits, so that the number of relocations needed is minimal. When discharging a vessel, it is important that quay cranes discharge the load correctly and that there are enough towing vehicles for a quick and efficient transhipment.

The main goal of the optimization of technological processes during loading/discharging operations is to minimize the time the vessel spends at the berth with a balanced and economical utilization of quay cranes and to maximize the containers' throughput.

Daganzo (1989) examined the problem of scheduling quay cranes in ports. In his work, the ships were divided into holds and only one crane could work at a certain hold at a given moment. The objective was to handle all the ships and thus to lower the total cost of delay. Peterkofsky and Daganzo (1990) further analysed the scheduling problem as an "open shop" scheduling problem with parallel, identical machines (quay cranes), where jobs consisted of independent, single-stage tasks. An integer program was developed with the goal of reducing costs of vessels' delay and a branch-and-bound algorithm was suggested for finding the optimal solution to the scheduling problem. The main feature of the algorithm was the fact that the search for a solution was restricted only to a certain kind of ships' departure schedules. Randomly generated test problems were used in order to test the branch-and-bound algorithm, and the results showed that the quality of algorithm solutions decreased rapidly as the complexity of the problem increased $[9, \mathrm{pp} .20]$. 
On the basis of the above mentioned results, Daganzo (1990) further analyzed the impact of the quay crane work on ship handling in ports, assuming that the workload distribution (over time) on ships at berths is equal to the workload distribution in total. In that study, he presented his interpretation of the impact that different quay crane scheduling strategies have on the maximal throughput and on vessels' delay. Tabernace (1995) applied learning concept to quay cranes in order to determine the relation between the number of moved containers and the duration of the discharging. The results showed that the work of the cranes improves with time and that it is not related to the size of the vessel. Kim and Park (2003) studied the problem of scheduling quay cranes to do a certain sequence of loading and discharging tasks with a view to reducing the ship handling time at the terminal. A mixed-integer linear program was developed and a branch-and-bound algorithm was proposed to solve that problem [9, pp.21-22].

\subsection{The container stacking process}

Container storage yard is a transitional area for handling incoming and outgoing containers. Containers may arrive in the terminal several days before the ship's arrival and they can leave the terminal several days after the ship. Containers are stacked in the yard in such a way that the time needed to transport them onto the ship or from the ship is as short as possible, so that the time that the ship spends at the berth is minimal.

A larger amount of storage space means a smaller number of unproductive container movements, but it requires bigger investments and this is sometimes impossible to achieve in practice. The capacity of the storage space, the effort needed for handling and storage strategies are all closely related factors that are always in interaction with each other.

Numerous studies have been carried out on the yard storage planning problem with a view to optimising the relation between the cost of space and the handling effort needed in various strategies.

Kim and Bae (1998) examined how to arrange export containers in the storage yard. They used a cost model in order to determine the optimal amount of space and the optimal number of transfer cranes for a certain group of import containers. In 2002 , they extended their study made in 1998, taking into account the level of service to customers, which was measured in terms of the delivery time of outside trucks. Preston and Kozan (2001) studied the problem of determining optimal strategies of storing containers for different container loading schedules. A container location model, which was a mixed-integer linear program, was developed in order to reduce the time of handling vessels in the terminal. The mixed-integer linear program proved to be NP-hard and a genetic algorithm was proposed to solve the problem. The data on real terminal operations confirmed the proposed model, therefore it could be used to assess future developments in the terminal [9, pp.24]. 
The yard space allocation problem is another important planning problem related to efficient utilization of storage space. The space allocation problem can be divided into three subcategories:

$>$ determining the number of blocks or stacks that can be assigned to a certain vessel

$>$ determining the number of containers of a vessel that can be stored in each block, and

$>$ determining the exact location for the containers.

Some investigators studied the yard space allocation problem. Most of the former studies focused on solving the first two sub-problems.

A number of investigators have focused on export containers and presented a dynamic space allocation method with a view of using the storage space efficiently and increasing the effectiveness of loading operations. A basic mixed-integer program model was formulated; two heuristic algorithms were compared in computational experiments: a myopic rule (least-duration-of-stay) and a sub-gradient optimization technique. The results were of approximately equal quality, but the decision rule was significantly faster. The effects of changing values of some parameters in the model were analysed as well [9, pp.25].

Zhang et al. (2003) studied the storage space allocation problem in a complex terminal yard, where incoming, outgoing and transit containers are all mixed together. The problem was solved using a rolling-horizon approach. For each planning horizon, the problem was divided into two levels. On the first level, the total number of containers to be placed in each storage block in every time period was determined, so as to balance the two types of workloads among blocks. On the second level, the number of containers linked to each ship was determined, which created the total number of containers in each block, for every time period. The objective was to achieve the minimal distance between the containers' storage blocks and vessels' berths. Computational experiments showed that with that method imbalances in the yard are significantly reduced, as well as the possibility of bottlenecks in the terminal [9, pp.25].

One of the problems in the research was the problem of determining the exact storage location for incoming export containers at port container terminals. The objective was to determine the storage place in a pre-assigned yard bay for an incoming export container of a certain weight group. The configuration of the container stack, the containers' weight distribution in the yard and the weight of the incoming containers were all taken into account. To solve the problem optimally, a dynamic programming algorithm was proposed. Since the computational time required by the dynamic programming algorithm was too long, in order to solve the problem, a decision tree based method was developed. The results of the method were assessed on the basis of the number of wrong decisions when compared to the optimal solutions offered by the dynamic programming algorithm. Computational experiments showed that the percentage of wrong decisions was low - between $1 \%$ and $5.5 \%$ [9, pp.26]. 
Yard cranes are the most often used equipment for loading containers onto towing vehicles or unloading them from towing vehicles in port container terminals. But since such equipment is bulky, yard crane work usually causes bottlenecks in the container handling flow. Therefore, it is necessary to create good yard crane schedules to achieve high terminal throughput. Considering the features of yard crane operations, there are two frequent problems encountered when it comes to allocating and scheduling yard cranes:

$>$ how to use a crane efficiently within a block, that is, how to schedule the sequence of tasks for the crane in a block, and

$>$ how to deploy and schedule cranes among blocks [9, pp.24].

During the process of vessels loading and discharging, a fleet of towing vehicles needs to transport the containers between the yard and the vessels at the quayside. The usual equipment used for transportation in the terminal includes trucks, trailers, automatic-guided-vehicles (AGVs) and manned or automatic straddle carriers. Scheduling and directing the vehicles efficiently can speed up the container handling process, facilitate the flow of containers between the quayside and the yard, and thus increase the terminal's productivity. Determining the size of the fleet in the transportation system is a fundamental decision, as the system capacity is directly related to the number of available vehicles. Determining the optimal number of towing vehicles for a certain system requires a compromise between investment costs and possible consequences caused by not fulfilling all the demands.

One of the main problems in planning a terminal is determining the sequence of containers to be handled by a towing vehicle. The decision about the sequence largely impacts the performance efficiency of both the quayside and the yard. The unnecessary vehicles' waiting time leads to a longer handling time in the terminal. At large container terminals, organizing the vehicles efficiently and effectively can improve the productivity of the container handling process, facilitate the flow of containers between the quayside and the yard, and thus increase the terminal's productivity [9, pp.37].

When handling a container, both towing vehicles and quay cranes/yard cranes must be available to ensure an uninterrupted flow of containers. If a vehicle finds that the quay crane/yard crane is busy with handling containers for other towing vehicles, it will join the crane queue and wait for the crane to become available. Similarly, if the quay crane/yard crane does not have a towing vehicle underneath, it will wait idly until a towing vehicle that requires handling arrives. Normally, there are huge numbers of containers that need to be loaded or discharged at a terminal every day. In order to reduce the handling time in the terminal, it is extremely important to ensure an efficient and effective transportation of containers between the quayside and the yard using towing vehicles.

There are numerous studies in scientific literature dealing with problems of optimization and allocation of towing vehicles [9, pp.29-33].

Du and Hall (1997) analysed fleet sizing and empty vehicle redistribution for a one-to-many transportation structure. Terminals were classified into surplus and shor- 
tage terminals based on the balance between incoming and outgoing transportation requests. An appropriate fleet size was determined on the basis of the inventory control theory. The assumption was that operative costs are created if the number of vehicles is too big, while shortage costs arise if the number is too small.

Vis et al. (2001) presented a model and an algorithm for determining the required number of automatic-guided-vehicles at an automated container terminal. A network flow based model and a polynomial time algorithm were developed in order to solve the problem in which containers were available for transportation at a known moment. Most studies focused on the second and the third problem, which are closely related to the famous travelling salesman problem (TSP), Multiple TSP (M-TSP), and to general vehicle routing problems (VRP) and their variations.

Chen (1998) studied the problem of dispatching automatic-guided-vehicles to containers. Other decisions were also taken into account, such as determining the yard storage location for import containers, routing automatic-guided-vehicles and controlling the traffic. A greedy algorithm was developed to solve that problem. In the case of only one vessel with only one crane, the greedy algorithm was optimal. In their algorithm, automatic-guided-vehicles were assigned to first available containers. After that, the next container was assigned to the first available towing vehicle. In the case of only one vessel with several cranes, the greedy algorithm assigned the available automatic-guided-vehicle to the first available crane. Although in that case the greedy algorithm did not necessarily find optimal solution, their simulation experiment showed that the solutions were close to optimal.

Kim and Kim (1999) dealt with the problem of routing straddle carriers for loading export containers. The goal was to reduce the total distance of the straddle carriers. The routing problem consisted of the container allocation problem, which was formulated as a transportation problem, and a carrier routing problem. Also, the sequence of yard bays that the carrier needed to visit was determined. A beam search algorithm was developed to solve the problem, and it was evaluated on the basis of a series of test problems. Computational results showed that the suggested algorithm was of a very high quality. In Kim and Kim's (1999) study the number of containers that a straddle carrier picks up at each bay was determined, as well as the sequence of visiting bays, in order to minimize the straddle carrier's total distance and the time spent. The proposed integer programming model was solved using a two-phase procedure, but the sequence of individual containers was not studied.

Bish et al. (2001) examined the problem of scheduling trucks under the assumption that the yard crane is always available to handle the towing vehicle. The objective was to determine the storage location for each discharged container. In their study, the yard crane constraint was relaxed in order to get an insight into a more complex problem. The problem of scheduling towing vehicles, whereby the container storage location for each type of vessel is predetermined, proved to be NP-hard. Therefore, it was computationally very difficult to find the optimal solution for scheduling equipment and for container locations using only one model. Bish (2003) studied the problem of 
determining the storage location for every discharged container, dispatching the vehicles to containers, and scheduling quay cranes' loading and discharging tasks under vehicle pooling policies, with a view to reduce the maximum time needed for handling a certain group of vessels. The problem was formulated as a transhipment problem, and a heuristic algorithm was proposed to solve it.

Qiu et al. (2002) made a review of algorithms for scheduling and routing automatic-guided vehicles. They presented similarities and differences between certain algorithms, and also problems related to them, such as the problem of routing vehicles, the shortest path problem, scheduling problems etc. They divided algorithms into the following categories: general path topology (static, time-window-based and dynamic methods), path optimization (0-1-integer-programming model, intersection graph method and integer linear programming model), specific path topologies (linear, loop and mesh topologies) and dedicated scheduling algorithms.

Li and Vairaktarakis (2004) dealt with the problem of reducing vessels loading and discharging time at a container terminal with a fixed number of towing vehicles, without sharing among different vessels. An optimal algorithm was developed for the case with only one quay crane. The efficiency of the heuristic algorithm was demonstrated through analysis and computational experiments. The optimal algorithm was efficient when the number of towing vehicles was small (for example, two or three vehicles). Heuristic algorithms were able to solve the case with a larger number of vehicles when the worst-case error bound was $100 \%$, and the expected relative errors approached zero exponentially as the number of tasks increased. The case of several identical quay cranes was not solved, but its complexity was analysed.

Grunow et al. (2004) focused on dispatching automatic-guided vehicles with multiple loads. A flexible priority rule based approach was proposed and it was compared to an alternative mixed-integer programming in various scenarios. Automatic-guided vehicles with multiple loads proved to be less delayed, therefore, an improvement in the entire terminal's operation can be expected. A mixed integer programming was then developed, which allows determining optimal solutions for smaller problems.

Hartman (2004) developed a general model for various scheduling problems that arise at container terminals. The scheduling model consisted of assigning tasks to the resources and temporarily allocating tasks subject to precedence constraints and sequence-dependent setup times. That model can be applied in scheduling towing vehicles, automatic-guided vehicles, straddle carriers, container cranes and even employees. To solve the problem, a heuristic method based on priority rules and a genetic algorithm was considered and they were compared in a computational experiment. The results were promising and they showed that the genetic algorithm was appropriate for practical use.

Jula et al. (2005) studied the problems of scheduling towing vehicles for transportation of containers and planning routes in city zones near sea ports. Their objective was to minimize empty movements and to improve customer service. They showed that the container movement problem using towing vehicles with time constraints at 
both origins and destinations could be formulated as an asymmetric multi-travelling salesmen problem with time windows with additional social constraints. They also examined the sequence-dependent handling time in their study, but they did not take into account the job ready-time.

Nishimura et al. (2005) dealt with the trailer routing problem at a sea container terminal, where trailers were usually allocated to certain quay cranes until the work was finished. A more efficient method of allocating trailers, called "dynamic routing", was proposed. A heuristics was developed and a wide range of computational experiments was carried out. The results of the experiments showed that the dynamic routing reduces the distance of movements and leads to savings in terms of trailers' fleet size and in terms of general costs (15\% reduction).

\section{An efficiency analysis of the vessel transshipment operating processes}

For the analysis of the efficiency of the technological process at a container terminal, a quantitative method was used in this paper, namely, the queuing theory. There are numerous studies in scientific literature which have used this method in order to create a model for terminal's optimal functioning. We will mention only a few of them.

Zenzerović and Mrnjavac (2000) investigated published scientific and professional papers, in which the queuing theory methods were used, related to port systems modelling. On that basis, they supplemented the existing models and created new ones [7]. A study carried out by Zenzerović (2005) presented models that may be very useful for operative planning of existing or expected situations in making certain business decisions. The objective was to achieve the optimal functioning of the maritime container transportation [10].

Grdelj, Krčum and Twrdy (2009) examined methods and models related to container terminal operations. A Petri nets model was used in the paper for demonstrating vessels berthing operations, while a genetic algorithm was used for determining the schedule for loading/discharging containers by means of cranes; the goal was to minimize the total time needed to serve a certain number of vessels [4].

Par and Dragović (2009) investigated some important port system elements and on that basis they developed a simulation model for analysing the effectiveness of the Korean terminal [1]. El-Naggar (2010) conducted a study for the port in Alexandra, Egypt, in which he used the queuing theory method. In his paper, he described a model for making future crucial decisions related to determining the optimal number of berths to satisfy the future demand, and thus to reduce the port's costs. He developed an economic and mathematical model applied in the port [3].

In this paper, the analysis of the efficiency of technological processes was carried out for the port of Rijeka, using the queuing theory method [11, pp.20-26].

The fundamental parameters of port container terminals are the intensity of vessels' (or containers') arrivals and the intensity of handling them. The average number of 
container vessels (containers) that arrive at a terminal during the observed time unit is marked with $\lambda$. The parameter $\mu$ denotes the average number of container vessels or containers that can be handled within the time unit, at each berth, that is, it denotes the throughput capacity of one berth with one crane.

The level of workload of a handling place (a crane at a container terminal) is the ratio of the intensity of arrivals and the intensity of handling containers, and it is marked with $\rho$, whereby $\rho=\lambda / \mu$.

Other indicators are:

$>\mathrm{L}$ - the average number of containers in the system (queuing and being handled),

$>\mathrm{LW}$ - the average number of queuing containers,

$>\mathrm{LS}$ - the average number of containers being handled,

$>\mathrm{W}$ - the average time that a container spends in the system (waiting and handling),

$>\mathrm{WQ}$ - the average queuing time of a container,

$>\mathrm{WS}$ - the transhipment time of a container,

$>\mathrm{P} 0$ - the probability that there are no containers in the system, and

$>\mathrm{PW}-$ the probability that the container will wait for service.

According to the classification of waiting problems, a container terminal is a waiting system that allows for an infinite number of queuing ships, most often with the Poisson distribution for ships' arrival and their handling time, that is, with the mark $\mathrm{M} / \mathrm{M} / \mathrm{S} / \infty$. [12, p. 10]

An illustrative example in this paper is the port container terminal in Rijeka, covering an area of 16.8 ha, namely, its part with two berths and four cranes. The theoretical capacity of the cranes is $30 \mathrm{TEU} / \mathrm{h}$, while the true capacity is $22 \mathrm{TEU} / \mathrm{h}$. The following loading/unloading equipment is also found in the terminal: 6 yard cranes, 2 railroad cranes, 6 truck cranes, 9 tractors, 17 trailers and 3 forklifts.

The capacity for stacking empty containers and special cargo is $4500 \mathrm{TEU}$. Behind the second berth, there is a place for stowing full containers of total capacity equalling $4600 \mathrm{TU}$. The berths are located next to each other, so the load (regardless of the berth where the vessel for loading/unloading is located) can be stowed into both stowing places, depending on the type of the load (empty or full containers).

According to the data of the Adriatic Gate Container Terminal (AGCT) [13], the terminal's annual capacity is 450000 TEU. At the container terminal, vessels are currently being served at two berths, with two cranes at each of them. Assuming that every day two shifts with 14 hours of effective work are done, and taking into account the true capacity of $22 \mathrm{TEU} / \mathrm{h}$ of each crane, the handling intensity of one crane is 308 TEU/day. That is, the handling intensity $\mu=450000 / 365=1232.8767 \mathrm{TEU} / \mathrm{day}$ for four cranes, and $308 \mathrm{TEU} /$ day for one crane. The overturn of the terminal in 2014 was 149 $838 \mathrm{TEU}$, which means that the arrival intensity on a daily basis was $\lambda=149838 / 365$ $=410.515 \mathrm{TEU} / \mathrm{day}$. 
Table 1 - The analysis of the Rijeka port container terminal turnover in 2014

\begin{tabular}{|l|c|}
\hline Indicator & $\mathrm{S}=4$ \\
\hline$\lambda$ & $410 \mathrm{TEU} /$ day \\
\hline$\mu$ & $308 \mathrm{TEU} /$ day \\
\hline$\rho_{\mathrm{S}}$ & 0.33 \\
\hline $\mathrm{L}$ & $1.36 \mathrm{TEU}$ \\
\hline $\mathrm{Lq}$ & $0.026 \mathrm{TEU}$ \\
\hline $\mathrm{Lusl}$ & $1.334 \mathrm{TEU}$ \\
\hline $\mathrm{W}$ & $4.75 \mathrm{~min}$ \\
\hline $\mathrm{Wq}$ & $0.14 \mathrm{~min}$ \\
\hline $\mathrm{Wusl}$ & $4.61 \mathrm{~min}$ \\
\hline Po & $26.2 \%$ \\
\hline $\mathrm{P}_{\mathrm{W}}$ & $5.15 \%$ \\
\hline
\end{tabular}

Based on the results presented in Table 1, it is evident that the coefficient of utilization of the terminal with four cranes at the operational quay is $33 \%$. If two cranes had been used, the coefficient of utilization would have been $66 \%$, which means that for the 2014 turnover two cranes would have been enough. The efficiency of every container terminal is determined by the time each vessel spends waiting at the terminal, that is, the time a vessel spends queuing for an available berth, and the handling time of each vessel. The time can be reduced by increasing the number of berths, whereby additional investments are necessary for building berths and acquiring equipment. However, the terminal's turnover, as for the present, does not justify additional investments in the area and that would not be profitable under the current conditions. This is also shown by the waiting probability indicator, which is only $5 \%$.

The city of Rijeka is the shortest link between the Central and Central-Eastern Europe and the overseas destinations, both by land and by sea, and it has the most convenient geographic and traffic position; therefore, such an advantage should be used knowingly. However, comparative advantages of the Rijeka port are not the same as its competitive advantages. An excellent geographic position alone will not attract freight, unless competitive advantages are built up from the comparative ones. Important factors that need to be considered include the number of railway operators, the number of block trains, as well as their transition time and capacity in terms of length and the quantity of load they can carry. Besides, in order to achieve an efficient traffic route, it is necessary that all the subjects participating in the transportation chain, from the consignor to the final consignee, function efficiently. The port of Rijeka needs to attract the freight that arrives at other ports, which is a very difficult and complex task. Project management needs to be introduced, numerous functions need to be united and all the bottlenecks need to be detected and resolved. 


\section{Conclusion}

Because of increasing demand for an efficient handling of containers and because of demanding competition, loading and unloading of large numbers of containers in the most effective way is extremely important for every terminal. To achieve optimal work efficiency, terminals need to know how to arrange the arrival, reloading and departure of ships and to work on resolving the complex process of container transport between different parts of the port.

In this work, we have analyzed problems which are present on container terminals and which are very common in manager`s everyday life. The paper also presents a review of former researches concerning individual technological processes on terminal and resolving specific problems while performing the same processes with a proposal for measures which should be taken in order to make work at terminals more productive and their management more effective.

As soon as a ship arrives at port, it is important for the port to assign the right dock and to decide what number of cranes will be engaged in loading/unloading operations. Transport of containers between the dock and the container stacks can be decomposed into several individual processes according to the type of equipment involved. In most terminals, towing vehicles are usually used for container transport. One of the main problems with terminal's planning is to determine the number of containers and the order in which they should be processed. Decisions about the order are the main fact when it comes to efficiency of work on a dock and container stack. Considering the time the towing vehicles are wasting by waiting for the shore crane to pass on a container leads to prolonged processing of the ship and to this end an effective schedule should be developed for towing vehicles to assure effectiveness of terminal.

In order to optimize the work of terminal, methods need to be developed for planning and supervising different kinds of resources for container processing. The goal is to achieve excellent work performance and to reduce the processing time.

Considering the complexity of the procedure and difficulties in finding the optimal solution for the performance of operational processes on terminal through quantitative methods, such as the problem of assigning docks, minimization of time ships spend on terminal as well as organizing towing vehicles, it turns out that one of the most effective ways of dealing with these problems is to use the genetic algorithm. The subject of further research will be identification of the real problem concerning individual technological processes on terminal, researching the way for their improvement as well as the suggestion for solution including the above mentioned method. 


\section{Literature}

1. Dragović B., Park N.: A Study of Container Terminal Planning, Faculty of Mechanical Engineering, Belgrade, VOL. 37, No. 4, 2009., pp. 203-209.

2. Dundović Č.: Tehnološki procesi u prometu, Sveučilište u Rijeci, odjel za pomorstvo, Rijeka, 2001.

3. El-Naggar M. E.: Application of queuing theory to the container terminal at Alexandria seaport, Journal of Soil Science and Environmental Management, Vol. 1 (4), 2010, pp. 77-85.

4. Gudelj A., Krčum M., Twrdy E.: Models and methods for operations in port container terminals, Traffic and transportation, Vol. 22, 2010, No. 1, pp. 43-51.

5. Hashemia A., Helmia S.A., Nouredinb G., Shahpanaha A., Zahraeea S. M.: Reduction of Ship Waiting Time at Port Container Terminal Through Enhancement of the Tug/Pilot Machine Operation, Faculty of Mechanical Engineering, Universiti Teknologi Malaysia, Iran, 2014, pp. 63-66.

6. Hess, S., Hess, M.: Optimization of ship's operations by genetic algorithm, Promet Traffic\&Transportation 21(4), 2009, pp. 239-245

7. Mrnjavac E., Zenzerović Z.: Modelling of port container terminal using the queuing theory, European Transport, VI (2000) 15, pp. 54-58.

8. Šimunović Lj.: Teorija redova čekanja (queueing theory), Fakultet prometnih znanosti, Zagreb Zavod za inteligentne transportne sustave, 2012.

9. Yuxuan Z.: Scheduling Trucks in Port Container Terminals by a Genetic Algorithm, University of Hong Kong, Hong Kong, 2005.

10. Zenzerović Z.:Kvantitativne metode u funkciji optimalnog funkcioniranja sustava kontejnerskoga prijevoza morem, Pomorski zbornik 43(1), 2005, pp. 165-191.

11. Zenzerović Z.: Teorija redova čekanja, Stohastički procesi II. dio, Sveučilište u Rijeci, Pomorski fakultet u Rijeci, Rijeka, 2003.

12. Zenzerović Z., Vilke S., Jurjević M.: Queing theory in function of planning the capacity of the container terminal in port of Rijeka, Pomorstvo, Scientific Journal of Maritime Research, 25(1), (2011), pp. 45-69.

13. http://www.ictsi.hr/index.php/hr/ (rujan, 2015.) 
Katarina Ivanić, Svjetlana Hess

\section{Tehnološko-operativni procesi na kontejnerskom terminalu}

\section{Sažetak}

Cilj rada je istražiti tehnološke procese koji se provode na kontejnerskom terminalu. Svaki od njih predstavlja veliki izazov s kojim se susreće menadžer svake luke koji je odgovoran za organizaciju rada terminala. Tijek i način provođenja tehnoloških procesa treba organizirati na način da se minimizira provedeno vrijeme broda na pristanu, uz izbalansiranu i ekonomičnu iskoristivost lučkih kapaciteta te maksimalan protok kontejnera. Praćenje iskoristivosti lučkih kapaciteta u ovom je radu prikazano na primjeru kontejnerskog terminala riječke luke. Primjenom kvantitativne metode, teorije redova čekanja, istraženo je da li kapaciteti kontejnerskog terminala zadovoljavaju postojeći promet te da li su dovoljni za buduća povećanja prometa u smislu ili proširenja postojećih ili bolje organizacije tehnoloških procesa.

Ključne riječi: tehnološki procesi, kontejnerski terminal, lučki kapaciteti, iskoristivost 
